\title{
Demi Kopi; Apresiasi Tari Pong Tiku Karya Ridwan Aco
}

\author{
Zulkifli Makmur \\ Sekolah Tinggi Agama Islam Darud Dakwah wal Irsyad Kota Makassar \\ zulkifli.makmur@mail.ugm.ac.id
}

\begin{abstract}
Abstrak
Artikel ini merupakan apresiasi penulis terhadap pertunjukan Tari Pong Tiku karya Ridwan Aco yang dipertontonkan di Taman Laki Padada Kabupaten Tana Toraja, Sulawesi Selatan. Peristiwa tari tersebut merepresentasikan perjalanan Pong Tiku melawan penjajah di Perang Kopi di awal abad 20. Perang ini merupakan penutup segala perang kerajaan melawan Belanda di masa kolonial Hindia-Belanda. Tari kolosal yang digarap Ridwan Aco ini merefleksi kekayaan alam, budaya, dan sejarah yang pernah dimiliki masyarakat Toraja di masa lalu.
\end{abstract}

\section{Pendahuluan}

Di pusat kota Makale, senin pasca natal tak jauh dari kolam Lakipadada, seorang lelaki pemberani berjalan berderap dengan garang. Semangat itu menulari siapapun yang melihatnya. Mereka bergerak berirama mengikuti emosi sang pemimpin menerobos rintangan demi menyelamatkan kota yang genting oleh serangan para penista kemanusiaan. Lelaki yang diikuti itu terus bergerak ke selatan hingga tiba di benteng Alla. Tak peduli nyawa menjadi taruhannya asal negeri kembali tenteram dan penjajah tak lagi menginjakkan kaki di bumi Toraya.

Peristiwa patriotik tersebut disuguhkan ke dalam bentuk komposisi tari dalam salah satu rangkaian perayaan Lovely December di Makale-Toraja. Adalah Ridwan Aco koreagrafer peracik tari bertajuk Pong Tiku tersebut. Pong Tiku yang juga dikenal dengan nama Ne' Baso merupakan satu di antara sekian banyak pahlawan nasional di negeri ini yang jarang diperbincangkan. Tari Pong Tiku merefleksikan secara kronologis perang Kopi yang dipimpin oleh anak dari Siamo Karaeng ini.

Tari Pong Tiku diawali dari penggambaran dunia sebelum negeri Toraja diamuk perang. Melalui alunan musik yang merepresentasikan alam yang teduh, kontemplatif dengan sentuhan bunyi flute yang lembut, Toraja di atas panggung terlihat begitu damai. Di segmen ini panggung didominasi perempuan. Perempuan-perempuan ini masing-masing memegang sapu lidi. Penari-penari tersebut mengayunkan lidi ke atas dan ke bawah. Gerakan ini dapat ditangkap tak hanya merepresentasikan aktivitas domestik perempuan, namun mengisyaratkan tindakan menghalau; menghalau hewan-hewan buas, menghalau apapun yang berpotensi mengganggu ketenteraman penghuni rumah.

Penari-penari perempuan ini di segmen yang lain juga menggunakan properti sarung hitam khas Toraja dalam permainannya. Mereka menggambarkan wajah bukit dan gunung-gunung menjulang tempat Pong Tiku dan pasukan-pasukannya bersembunyi saat perang melawan Belanda. Alam di atas panggung 
dimainkan melalui tubuh-tubuh perempuan. Tarian ini menyelaraskan perempuan dan alam. Keduanya memiliki banyak kesamaan dalam kacamata kebudayaan Toraja.

Sedangkan penari pria bergerak berirama, bermain, menghibur, dan melindungi kekasih-kekasih mereka, ditandai dengan gerakan berayun di dalam sarung yang digantung di leher lelaki-lelaki mereka. Di babak selanjutnya, genderang ditabuh saling memburu. Tokoh Pong Tiku menengadahkan tangannya seakan memberi ajakan perlawanan terhadap musuh. Pria dan wanita bekerja sama, berderap langkah yang sama. Ritme langkah mereka sesekali pelan, sesekali cepat. Meskipun berubah-ubah, ritme langkah mereka tetap satu mengikuti ritme sang pemimpin.

Peristiwa Pong Tiku yang diangkat di panggung Pasar Seni Makale, Kabupaten Tana Toraja merupakan abstraksi dari peristiwa Perang Kopi yang terjadi di tahun-tahun pembuka abad 20. Perang Kopi adalah perang besar di Toraja yang diawali dari sengekta jalur perdagangan kopi antara kerajaan di Toraja yang dipimpin oleh Pongtiku dan Belanda. Pergolakan Perang Kopi merajut rentetan proses memerdekakan nusantara dari campur tangan asing. Tercatat Perang Kopi merupakan perang fisik terakhir di nusantara melawan dominasi Hindia-Belanda. Saat tokoh-tokoh pergerakan kemerdekaan di masa tersebut berjuang melalui ruang-ruang resmi, dengan jas bergaya kolonial, Pong TIku justru menyeberangi gunung, lembah, dan sungai demi menjaga tanah dan makam-makam leluhur.

Refleksi wangi kopi yang memancing keserakahan tetamu untuk menguasai negeri ribuan tongkonan ini dapat tercium melalui tari Pong Tiku. Sepertinya melalui simbol-simbol yang tersebar di tubuh penari-penarinya, Ridwan Aco memainkan isu yang melampaui nilai-nilai patriotisme. Ia berusaha menariknya jauh ke kedalaman hakekat manusia sebagai pemimpin; sebagai anak; dan sebagai entitas sederhana dari alam.

\section{Penutup}

Kematian Pong Tiku yang digambarkan dengan tubuh yang berdiri tegak dan pose kedua tangan yang terbuka-mungkin terlalu berlebihan jika penulis menggambarkannya-menyerupai tangan patung Jesus di puncak Makale adalah isyarat penting di era keruntuhan modernitas. Manusia modern yang kerap berganti-ganti identitas sesuai tuntutan pop ini lupa asal-muasal dirinya. Kelupaan ini menciptakan individu yang mudah goyah oleh tekanan. Oleh karena itu, ajakan untuk kembali bersua dengan alam kerap didengungkan. Alam adalah tempat ruh-ruh pendahulu bersemayam. Caranya menyatunya? Mungkin dengan meneguk secangkir kopi Toraja.

\section{Rujukan}

Makmur, Z. (2020, October 22). Negeri Berlinang Mitos (sebuah Ulasan Novel "Negeri Lima Menara" Karya Ahmad Fuadi). https://doi.org/10.31219/osf.io/tqc4j 
Makmur, Z. (2020, October 22). Penjurian Sastra di Masa Kebiasaan Baru.

https://doi.org/10.31219/osf.io/5vymt

Makmur, Z. (2020, October 17). Film Snowden; antara Paranoia dan Tipuan-Tipuan Klasik Amerika. https://doi.org/10.31219/osf.io/9hgc7

Makmur, Z., \& Sainuddin, I. H., S. (2020, October 10). Karenang di atas Canon (sebuah Apresiasi). https://doi.org/10.31219/osf.io/k6r94

Makmur, Z. (2020, October 13). Paradoks Hubungan antara Manusia, Lingkungan, dan Sains dalam Enam Sekuel Film Final Destination (Sebuah Pendekatan Self-Deconstruction).

https://doi.org/10.31219/osf.io/eacgs

Makmur, Z. (2020, September 10). Dekonstruksi puisi "The Divine Comedy" karya Dante Alighieri dalam Novel "Inferno" karya Dan Brown. https://doi.org/10.31219/osf.io/cwypx

HERIANTO, H., Jusmiana, A., Jusmawati, J., \& Makmur, Z. (2020, June 21). Comparing Learningat-home Activities of Students Living in Cities and Those Living in Villages during the Covid-19 Pandemic. https://doi.org/10.31219/osf.io/m4x9b

Alwi, A. M. S., Arsyam, M., Sainuddin, I. H., S, \& Makmur, Z. (2020, August 18). PELESTARIAN LINGKUNGAN SEBAGAI IMPLEMETASI DAKWAH BI AL-HAL DAN WUJUD KESADARAN MASYARAKAT. https://doi.org/10.31219/osf.io/vf6qm

Makmur, Z. (2020, August 2). Membangun Kesadaran Apokaliptik melalui Sastra di Masa Pandemi. https://doi.org/10.31219/osf.io/utvyk

Makmur, Z., Sainuddin, I. H., S, Arsyam, M., \& HERIANTO, H. (2020, July 4). Paradoxical Relationship between Humans, the Environment, And Science in Final Destination (Movies). https://doi.org/10.31219/osf.io/ukr4q 